\begin{tabular}{|c|c|c|}
\hline Review Article & $\begin{array}{l}\text { Yönetim, Ekonomi, Edebiyat, } \\
\text { İslami ve Politik Bilimler }\end{array}$ & $\begin{array}{l}\text { JOMELIPS - Journal of } \\
\text { Management Economics Literature }\end{array}$ \\
\hline Araştırma Makalesi & Dergisi,3(1): 70-89, & Islamic and Political Sciences \\
\hline DOI: 10.24013/jomelips.429389 & 30 Haziran/June, 2018 & e-ISSN :2547-9512 \\
\hline
\end{tabular}

\title{
Restoran Seçiminde Tüketiciyi Etkileyen Faktörlerin DEMATEL Yöntemiyle Değerlendirilmesi: Bir Uygulama
}

\author{
Ekrem BADEM $^{1^{*}}$ \\ ${ }^{1}$ Bartın Üniversitesi, Sosyal Bilimler Enstitüsü, İşletme Ana Bilim Dalı, Yüksek Lisans \\ Öğrencisi \\ ebadem@bartin.edu.tr \\ Dr. Öğr. Üyesi Ahmet ÖZTEL ${ }^{2}$ \\ ${ }^{2}$ Bartın Üniversitesi, İ.İ.B.F. , İşletme Bölümü \\ aoztel@bartin.edu.tr
}

\begin{abstract}
ÖZ
Hizmet sektörü içerisinde yer alan restoran işletmeciliği sadece dişarıda yemek yeme olgusunu karşılamakla kalmayıp, aynı zamanda müşterilerin iyi vakit geçirme, sosyalleşme, dinlenme gibi ihtiyaçlarının karşılandığı müesseseler haline gelmiştir. Tüketici alternatiflerinin yoğun olduğu günümüzde restoran işletmeleri, rakiplerine üstünlük sağlamak için müşterilerin talepleri doğrultusunda hareket etmek zorundalardır. $\mathrm{Bu}$ çalışmanın amacı, bir hizmet işletmesi olarak restoranların tüketici tercihini etkileyen faktörlerini belirlemek, faktörler arası ilişki düzeylerini ve önem derecelerini saptayarak restoran seçimi uygulamasını gerçekleştirmektir. DEMATEL yöntemi faktörler arasındaki ilişkiyi nicel olarak ifade etmek için uygun bir yöntemdir. Bu çalışmada, Bartın Üniversitesi'nden uzman akademisyenlerin görüşleri alınmış ve restoran seçimini belirleyen faktörler DEMATEL yöntemi ile incelenmiştir. Yapılan analizde restoran seçiminde en yüksek etkiye sahip faktör, "hizmet kalitesi" olur iken, en düşük etken ise, "fiyat" olarak tespit edilmiştir.
\end{abstract}

Anahtar Sözcükler: Restoran Seçimi, DEMATEL Yöntemi.

\section{The Evaluation of Factors Affecting the Consumer in Restaurant Selection by Using the DEMATEL Method: An Application}

\begin{abstract}
The restaurant operations within the service sector not only meet the eating out situation but also become the establishments where the customers meet their needs such as having a good time, socializing and resting. Today, where consumer alternatives are intense, restaurant operators have to act in line with customers' demands in order to be superior to their competitors. The aim of this study is to determine the factors affecting the consumers of restaurants as a service operation, to realize the restaurant selection application by

*Sorumlu Yazar (Corresponding Author):

Bartın Üniversitesi, Sosyal Bilimler Enstitüsü, İşletme Ana Bilim Dalı, Yüksek Lisans Öğrencisi

Geliș (Received) : 01.06 .2018

Kabul (Accepted) : 28.06.2018

Basım (Published) : 30.06 .2018
\end{abstract}


determining the relation levels and importance ratios between the factors. The DEMATEL method is an appropriate method to quantify the relationship between factors. In this study, the opinions of expert academicians from Bartın University were taken and the factors determining the restaurant selection were examined by DEMATEL method. As a result of the analysis, the factor that has the highest effect on restaurant selection is "service quality" while the lowest factor is determined as "price".

Keywords: Restaurant Preferences, DEMATEL Method.

\section{GÍRIŞ}

Hizmet işletmesi içerisinde yer alan yeme içme sektörü yoğun rekabet koşullarıyla birlikte gün geçtikçe büyüme eğilimi göstermektedir. Küreselleşen ve gelişen teknolojiler, kadınların çalışma hayatına atılması, gelir düzeyindeki artışlar, evde yemek yapmak için gereken zamanın kısıtlı olması ile sosyalleşme olgusu, insanların dışarıda yemek yeme alışkanlıklarında değişimlere sebep olmuştur.

Yemek ihtiyacının dışarıda karşılanması sanayileşme ve kentleşme ile birlikte modernleşmenin etkisiyle Batı Avrupa' da ortaya çıkmıştır (Akarçay ve Suğur, 2015, s. 2). Dışarıda yemek yeme olgusu ülkemizde son yıllardaki ekonomik gelirlerindeki ve teknolojik gelişmelerle birlikte kişilerin yaşam tarzları ve buna bağlı olarak tüketimlerinde meydana gelen artışlar sebebiyle yükseliş göstermektedir (Yüksekbilgili, 2014, s. 6353). Dışarıda yemek yeme kısaca yemek ihtiyacının ev dışı yiyecek ve içeceklerle karşılanması durumudur. Ticari düzlemde ise ev harici herhangi bir işletme tarafindan bir ücret karşılığında üretilen ve servis edilen yiyecek ve içeceklerin tüketimini ifade eder (Özdemir, 2010, s. 218). Dişarda yemek yeme olgusu ve buna duyulan ihtiyaç yiyecek-içecek sektörünün gelişmesinin en önemli sebeplerinden birisidir (Bekar ve Dönmez, 2016, s. 3). $\mathrm{Bu}$ sektör müşterilerinin sadece dişarda yemek yeme olgusunu karşılamakla kalmayıp bunun yanında onların yemekten zevk almalarına, hoşça vakit geçirmelerine, zamandan tasarruf etmelerine, dinlenme ve rahatlamalarına olanak sağlamaktadırlar. Ayrıca iş toplantılarına ev sahipliği yaparak insanların itibar kazanma gibi hususlarına yardımcı olmaktadir.

Frost ve Sullivan'ın yaptığ “Türkiye Cash \& Carry Pazarı" araştırmasına göre, 2015 yılına kadar Türkiye'deki restoran miktarında yıllık ortalama \% 5,1'lik yükseliş tahmin edilmiştir (Arıker, 2012, s. 11). Şaylan (2012)' a göre 2011 yılı verilerinde Türkiye' de aileler bütçelerinin \% 30' luk kısmını beslenmeye ayırmaktadır. Aile gelirlerinin \% 30' luk dilimi ayırdığı bu bütçenin \% 13' lük payı ise dişarıda yemek için harcanmaktadır. ABD' de ise beslenme bütçelerinin yaklaşık \% 50' lik kısmını ev dışı beslenmeye ayrılmaktadır. AB ülkelerinde (Almanya, Fransa, İngiltere vs.) hazır yemekten yararlanan kişi sayısı ortalama 65-70 milyon iken ülkemizde bu rakam 8 milyon civarındadır. Yapılan araştırmalar ve veriler hazır yeme- içme sektörümüzün her geçen yılda en az \% 20-25,2 lik bir büyüme kapasitesine sahip olduğunu göstermektedir (URL-1, 2012).

$\mathrm{Bu}$ verilerden de anlaşılacağ üzere ülkemizde çoğu gelişmiş ve gelişmekte olan ülkelerde olduğu gibi her geçen yeme-içme sektörü gelişerek dişarda yemek yeme alışkanlığı giderek artmaktadır. Yeme-içme sektörünün en dinamik halkalarından birisi de restoran segmentidir. Günümüzde restoranların pazarlama odak noktası müşterileridir. Benzer 
amaca yönelik çok sayıda işletme faaliyette olmasından dolayı restoranların böyle bir ortamda rekabet avantajı sağlaması büyük önem taşımaktadır. Bunun için en önemli unsurların başında müşteri memnuniyeti gelmektedir. Tüketiciler, alternatiflerinin fazlalığı, yaşam standardının artması, ekonomik ve teknolojik olanaklara ile restoran seçimlerini artık yalnızca fiyat faktörüyle değerlendirmemektedirler. Fiyatın yanı sıra müşteri memnuniyeti, restoranın ürün ve hizmet kalitesi, personel yetkinliği, atmosferi, güvenilirliği, tüketici tatmini ve değeri gibi bazı faktörler de tüketici karar verme sürecinde etkin rol oynamaktadır.

Yapılan araştırmalar ve çok sayıda çalışmalarda restoran seçimi tercihinde tüketicilerin birçok kriteri dikkate aldıkları görülmektedir. Bu çalışmada restoran seçimi kararını etkileyen beș önemli faktörün; mağaza atmosferi, fiyat, hizmet kalitesi, personel kalitesi ve ürün kalitesi faktörlerinin müşterilerin restoran seçimine olan etkileri araştırmıştır. Aynı zamanda bu faktörlerin birbiriyle olan ilişkileri ve birbirlerini etkileme derecelerini ölçmek amaciyla çok kriterli karar verme tekniklerinden biri olan DEMATEL (The Decision Making Trial and Evaluation Laboratory) yöntemiyle analiz edilmiştir. Ayrıca bu yöntem müşterilerin karar vermelerinde etkin rol oynayan araştırmamıza konu olan faktörlerin önem derecelerinin hesaplanmasına olanak sağlamaktadır.

\section{LITERATÜR TARAMASI}

Yiyecek ve içecek sektörü dünyada meydana gelen ekonomik buhranlarda bile devamlı büyüyen ve gelişen bir sektör olmuştur. Bunun asıl nedeni insanların fizyolojik yapılarından dolayı yeme ve içmenin insanlar tarafından her daim karşılanması gereken temel ihtiyaçlarından olmasıdır. Bu nedenle bu temel ihtiyaçların karşılanmasına yönelik hizmette bulunan kurumlar tarih boyunca oldukça fazladır. Sayıları artan yiyecek- içecek işletmeleri birbirleriyle rekabete girmiş ve bu durumda yiyecek-içeceklerin fiyatlarını düşürerek insanların dışarıda yemek yemelerine yol açmıştır (Rızaoğlu ve Hançer, 2013, s. 7).

İnsanların toplu olarak büyük gruplarla yemek yeme alışkanlıkları 12.000 yıl öncesine dayanmaktadır. Romalılarda ve antik Yunanlılarda banket 2 faaliyetlerine 2500 yıl öncesinde rastlanmaktadır Avrupa' da ayrı ve özel yemek yeme yerleri 1700' lü yılların ortasında faaliyete başlamıştır (Pırnar, 2015, s. 3). İkinci Dünya Savaşının ardından, kültürel ve sosyo-ekonomik koşulların savaş öncesine göre birçok değişim göstermesi ile birlikte bu değişimin insanlara daha farklı, yeni zevkler ve lezzetler sunmaya başladığı görülmüştür (Akarçay ve Suğur, 2015, s. 3).

Yeme-içme hizmet işletmeleri ile ilgili birç̧ok tanım yapılmıştır. Bölükoğlu (1988)' na göre yiyecek \& içecek hizmet işletmesi, yapısı, şekli, teknik donanımı gibi nicel, sosyal değeri, hizmet- ürün ve personel kalitesi gibi niteliksel olgular ile müşterilerin açlik ihtiyaçlarının karşılamasını mesleki olarak sağlayan sosyal, ekonomik ve disiplin altına alınmış örgüttür. Başka bir tanım da ise, Belgin (2010)' e göre hizmet işletmesi, fiziksel ürünler dişında ekonomide yer alan her türlü faydalı çalışma ve etkinliğin üretildiği yerdir(URL-3, 2010).

\footnotetext{
${ }^{2}$ Banket: Kutlama ya da ağırlama için gerçekleştirilen, insanların birbiriyle görüşüp konuşmalarına olanak sağlayan akşam yemeklerinin yapıldığı alanlar anlamına gelmektedir. ( Kaynak: http://camia.com.tr/otelciliktebanket-alani-nedir/ )
} 
Çelik (2012)' e göre yeme-içme sektöründe hizmet yemek ve servis hizmetidir. $\mathrm{Bu}$ sektörde kaliteyi; yemeğin leziz olmasının yanı sıra, yemek hizmetinin gerçekleştiği alanın ambiyansı, servis yapan personelin işine hakim olması, ürünün tazeliği, müşterinin kullanılan malzeme için herhangi bir kaygı duymaması gibi faktörler belirler. Bu tanımlar 1şığında hizmet işletmelerini, insan gayreti sonucu meydana gelen fiziksel olmayan ürünlerle müşterilerine doğrudan yarar sağlayan ve bu sağlanan yarar karşısında ticari bir kazanç sağlayan işletmeler olarak tanımlanabilir.

Hizmet sektörünün kapsadığ faaliyetler geniş bir alanı içermektedir. $\mathrm{Bu}$ alanlar, danışmanlık, mühendislik, sağlık, sigorta acenteleri, bankalar, telekomünikasyon șirketleri ve otel zincirleri gibi büyük uluslararası organizasyonlardan, restoranlar, taksiler, kuaförler gibi küçük ölçekli yerel işletmelere kadar uzanmaktadır (İnan, 2010, s. 2). Hizmet sektörü içerisinde yer alan yiyecek ve içecek sektörüne ait ilk sınıflama Standard Industrial Clasificition adıyla, Merkezi İstatistik Bürosu tarafindan İngiltere' de 1948 de yapılmıştır.1958, 1968 ve 1980 de yenilenmiştir. 9 ana gruptan oluşan bu sınıflamada ana gruplardan birini oluşturan ağırlama endüstrisinin alt branşlarından birisi de yiyecek ve içecek sektörüdür (Türksoy, 1997, s. 1). Bu grup aşağıdaki tabloda detaylı olarak verilmiştir.

Tablo 1. Otel ve Yiyecek \& İçecek Hizmetlerinin Sınıflandırılması

\begin{tabular}{|c|lr|l|}
\hline SINIF & GRUP & FAALIYET DALI \\
\hline 66 & & & Otelcilik ve Yiyecek \& İçecek Hizmetleri \\
\hline & 661 & & Restoranlar, Barlar ve Diğer Beslenme Üniteleri \\
\hline & & 6611 & $\begin{array}{l}\text { Evde Tüketime Dönük Hizmet Sunan Yiyecek \& İecek } \\
\text { Üniteleri }\end{array}$ \\
\hline & & 6612 & $\begin{array}{l}\text { Üretildiği Yerde Tüketime Dönük Yiyecek \& İçecek } \\
\text { Üniteleri }\end{array}$ \\
\hline & 662 & 6620 & Birahane ve Barlar \\
\hline & 663 & 6630 & Gece Kulüpleri \\
\hline & 664 & 6640 & Kantinler \\
\hline
\end{tabular}

Yiyecek ve içecek sektörünün alt grubunda yer alan restoranların geçmişi eski tarihlere dayanmaktadır. Restoran kelimesi köken itibariyle, Fransızca 'restore' den gelmekte olup, yeniden düzenlemek, formuna sokmak anlamına gelmektedir(Türksoy 1997, s. 2). Gürkan( 2015)' a göre ilk restoran,1760' l1 yılların Fransa'sında Boulanger adında bir kişinin besleyici ve şifalı olduğu iddiasıyla zindelik, tazelik anlamına gelen restaurers adını verdiği çorbalar yapıp sattığı dükkanlar açtı. Kendi dükkanı da restorante olarak adlandırdı(URL2, 2015). Ülkemizde ise restorancılık hizmetlerinin ilk olarak on beşinci yüzyılda kahvehanelerin kurulması ile başladığı kabul edilmektedir. Birçok ürünün bir arada satıldığı ilk restoran resmi kayıtlara göre 1879'da Konya'da açılmıştır. Cumhuriyet Dönemi'nde ise özellikle modernleşme çabalarının etkisi ile ülkemizdeki restoranların sayısı ve çeşitliliği hızla artmıştır. 1980'lerde turizm hareketlerinin yoğunlaşmaya başlamasının etkileri, restoranlara da sıçramış ve sadece yerli halka değil yabancılara da 
hizmet vermeyi amaçlayan uluslararası disipline sahip restoranların sayısı armaya başlamıştır (K1lıç, 2011, s. 34).

Restoranlar, müşterilerin huzurlu bir ortamda yemek yemelerine olanak sağlayan, tercih edilen yiyecek ve içeceklerin masalara servis sunumuyla hizmet veren yerler olarak tanımlanmaktadır. Restoran işletmelerinden oluşan restoran endüstrisi gittikçe büyüyen bir endüstri haline gelmiştir. Restoran işletmeleri bir yandan bulunduğu bölgenin ekonomisine katkı sağlarken diğer yandan da turizm endüstrisinde çalışanların istihdamına da olanak tanımaktadır (Albayrak, 2014, s. 191). Farklı görüşlere göre restoran tanımı yapılmış olmakla birlikte, Yıldız (2010)' a göre bugünkü anlamıyla bir yiyecek-içecek işletmesinin restoran sayılabilmesi için; müșterinin geldiğinde oturması için hazır bulunan bir masa ve sandalye, müşteriye sunulacak menüdeki yiyecek ve içeceklerin çeşitliliği, bu yiyecekiçeceklerin fiyatlandırılması ve sipariş alınan müşteriye yapılan sunum, özelliklerinin olmas1 gerekir.

Her geçen gün değişen dünya, ekonomik ve teknolojik gelişmelerle işletmeler artık aynı kalitede mal ve hizmetler üretip benzer fiyatlarla sunmaktadırlar. Hizmet anlayışı, ürün çeşitliliği ve müşteri profili gibi pek çok konuda farklılaşan işletmeler içinde en yaygin olanı restoranlardır (Zencir ve Kozak, 2014, s. 7). Bu yaygınlık aynı zamanda sektörde birçok rakiple mücadele etmek anlamına gelmektedir. İşletmelerin rakiplerinden bir adım önde yer alabilmeleri ürün ve hizmet kalitesinin farklılaşmasından ziyade sunulan hizmetin kalitesi ve hizmet değeri ile gerçekleşecektir (Yücenur ve diğ. 2011, s. 156). Tüm hizmet işletmelerinde olduğu gibi restoran işletmeciliği sektöründe de pazar oldukça kalabalıktır. Kotler (1974)' e göre restoranlar işletmeleri fiziksel olarak yemek sunmak için müşterilerine yiyeceklerin seçilmesi, hazırlanması, pişirilmesi ve sunulması hizmetlerini de sağlamaktadır. $\mathrm{Bu}$ bağlamda Kotler, fiyat ve kalite unsurlarının tüketicinin restoran seçimindeki en başta gelen belirleyici faktörler olarak ifade etmektedir. Pırnar (2015)' a göre restoranlar, sunulduğu hizmetin özelliğine göre; alışveriş merkezlerinde veya kalabalık yerlerde hizmet sunan restoranlar, lüks restoranlar, özgün temalı restoranlar ve standart restoranlar olarak başlica dört gruba ayrılmıştır.

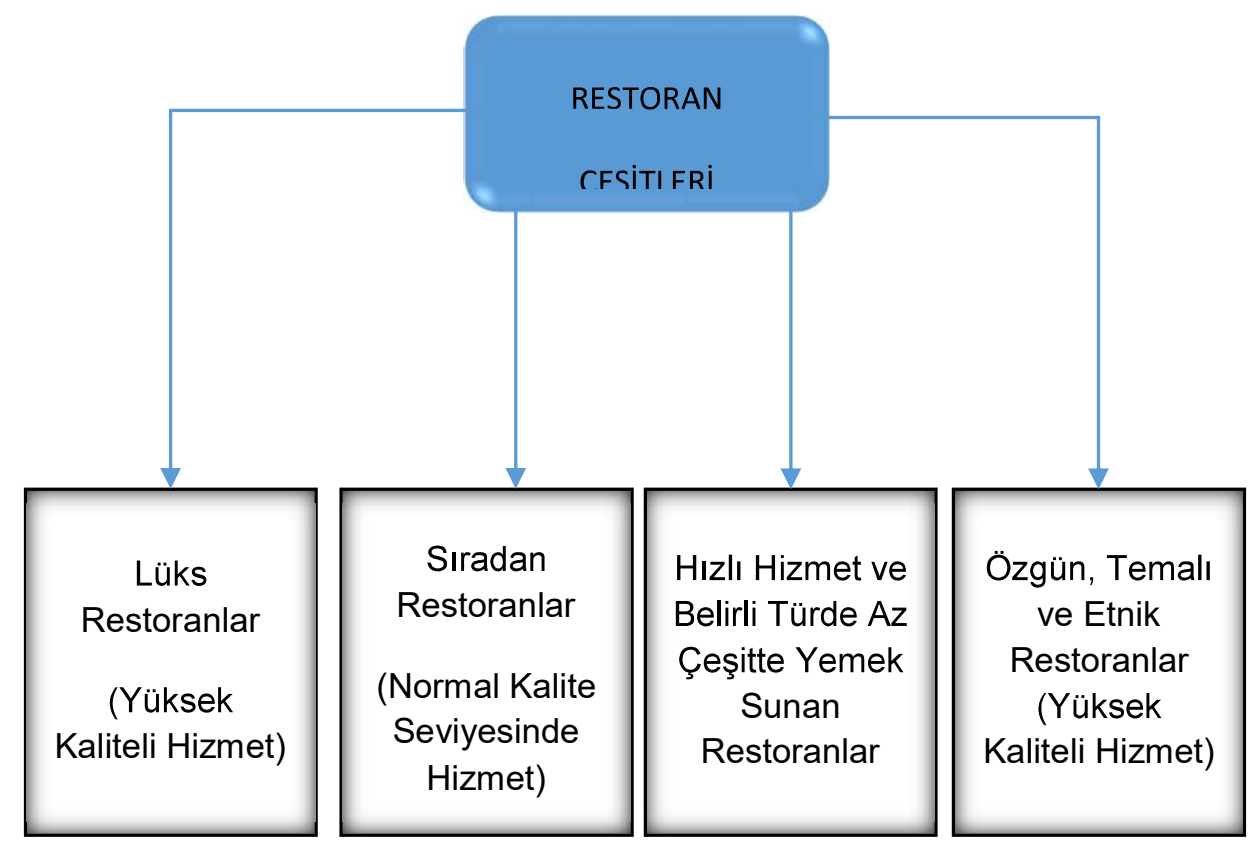


Şekil 1. Yiyecek ve İçecek İşletmeleri Sınıflandırılmasında Ticari İşletmeler olarak Hizmet Sunan Restoran Çeşitleri (Ninemeir, 1995; James ve Baldwin, 2003; Pırnar, 2015).

Lüks, seçkin restoranlar: Kalite standardı yüksektir. Sipariş üzerine hazırlanıp sunulan geniş menülere sahip olan bu restoranların mutfak ve servis iş gören sayıları oldukça fazla olmakla birlikte restoran elemanları eğitimli, deneyimi ve kalifiyelidir. Müşterilerinin uzun süreler restoranda kalmasını sağlayan resmi bir temasa sahip lüks restoranlar misafirlerinin kendilerini özel hissedeceği atmosfer ve dekora sahiptirler. Bu nitelikli sebeplerin yanı sıra yiyecek-içecek ve işçilik maliyetlerinin yüksek olmasından dolayı fiyatlar diğer restoranlara göre çok yüksektir.

Siradan, geleneksel restoranlar: Adından da anlaşılacağ1 üzere sıradan her bölgede çokça görülen restoran türüdür. Geniş bir menüye sahip garson servisli bu restoranların standart olmayan farklı bir atmosfer dekorları vardır. Fiyatlar orta seviyelerde seyretmektedir.

Hızlı yiyecek- içecek sunan restoranlar: Hazırda ve kolayda yiyeceklerin sunulduğu sınırlı menüye sahip olan bu restoran türleri daha çok alışveriş merkezlerinin belirli bir katında görülmektedir. $\mathrm{Bu}$ katta yoğunlaşan farklı restoranların kullanım alanları genellikle ortaktır. Müşteri yemeğini self servis olarak seçtiği restorandan alarak ortak kullanım alanlarındaki masalarda yiyebilmektedir. Self servis uygulaması olan restoranların iş gören sayısı haliyle oldukça azdır. Reklamlarla atmosfer yaratılan bu restoranlarda fiyatlar diğer restoran türlerine göre makuldür.

Özgün, etnik ve özellikli restoranlar: Et ve balık restoranları, vejetaryen restoranlar; Çin, Akdeniz, Ege Mutfağı gibi belirli kültüre odaklı restoranlar bu restoranlara örnektir. Sinırlı bir menüye bağlı olan bu restoranlar etnik karaktere uygun, çekici ve canlı bir atmosfere sahiptirler. Çalışanlar etnik kültürün özellikleri doğrultusunda özel olarak bilgili ve deneyim sahibidirler. Özellikli ve etnik unsurlar söz konusu olduğu için yiyecek-içecek ve işçilik maliyetleri yüksek olduğu için fiyatlandırmada buna bağlı olarak yüksektir.

Yiyecek-içecek sektörünün alt grubunda yer alan restoranların ekonomik krizlerde bile sayılarında artış görülmektedir (Pırnar, 2015, s. 3). Bunun en önemli nedeninin günümüzde insanların ekonomik gelirlerindeki artıştan dolayı olduğunu söylemek mümkündür. İnsanların satın alma gücündeki artışa ek olarak, sektörde hızlı bir rekabet söz konusu olduğu için kişinin evde yemek yapmak için harcayacağı tutar ile dişarıda ödediği tutar arasında çok büyük bir fiyat farkı olmayışıdır. Denizer (2008)' e göre ABD' de bir yılda dışarda yenen öğün sayısı yaklaşık 63 milyardır; dışarıda yenen yemeklerin \%31,9' u toplu yemek servislerinde iken \% 68,1'i de restoranlarda gerçekleşmiştir. Avrupa Birliğine üye dokuz ülkede yapılan araştırmaya göre ise, bir yılda yenen öğün sayısı yaklaşı 35,6 milyar olup, \% 44,7' sinin toplu yemek servislerinde, \%55,3' ünün de restoranlarda gerçekleştiği saptanmıştır. Dışarıda yenen yemeklerde ABD' nin Avrupa Birliği ülkelerine kıyasla sayısal oranda fazla olması yine bahsedilen satın alma gücünün daha fazla olması ve rekabet eden işletmelerin bir hayli fazlalığıdır. Ülkemizde de ev dişı yemek yeme alışkanlığı gün geçtikçe artmaktadır. 2013 yılındaki ekonomik dalgalanmalara rağmen 2014 yılı ev dışı yemek yeme cirosunun yıllık 20 milyar doları aştığı tespit edilmiştir. Turizm, Restoran Yatırımcıları ve İşletmecileri Derneği (TURYID) verilerine göre 2009' dan 2012' ye kadar geçen sürede y1llk bazda $\% 20$ ila $\% 25$ ' lik bir büyüme meydana gelmiştir. Ayrıca Target Group İndex (TGI) Türkiye' nin yapmış olduğu araştırmaya göre, 
ülkemizin kent nüfusunun her 10 kişiden yaklaşık 4' ünün dişarda yemek yediği sonucuna varılmıştır (URL-4, 2014). Araştırma sonuçlarında da görüldüğü üzere insanlar her geçen gün yeme-içme ihtiyaçlarını dışardan sağlamaktadırlar.

Ülkemizde ve dünyada hizmet işletmesi içinde artarak büyüyen, farklı statü ve gelir düzeyinde müşteri yelpazesine sahip restoran sektöründeki bir işletme rakip işletmelerle rekabet edebilmek, kar marjını yüksek tutabilmek ve sahip olduğu müşteri kitlesini elinden kaçırmamak için müşteri memnuniyetine önem vermesi gerekmektedir. Müşteri memnuniyetinin sağlanması işletmenin müşteri odaklı hareket etmesiyle mümkündür. İşletmeler, günümüz yenilenme çağında tüketicilerin devamlı yenilenen isteklerini karşılamak adına araştırma ve geliştirmeye önem vermeli ve bu araştırmalar neticesinde belirlenen beklentiler çerçevesinde yenilikçi olmalılardır. Bunun için işletme bünyesinde çalışan personelin eğitimine önem verilmelidir(Karakaş ve diğ. 2017, s. 615).

Pırnar (2012)' e göre müşteri odaklı bir pazarlama yaklaşımını benimseyen restoran yönetiminin dikkat etmesi gereken hususları şu şekilde sıralanmaktadır.

- Müşteri ilişkileri yönetiminde, daimi müșterilerin özel isteklerine göre hizmet sunmak. Onlara isimleriyle hitap etmek.

- Leziz bir yemek sunabilmenin yanı sıra, müşterilerin egolarının da tatmin edilmesi gerekmektedir. Müşterinin restoran yönetimi için özel oldukları hissettirilerek (doğum günü mesajları, restoranda çekilmiş resimlerinin restoran duvara asılması gibi) restoran hakkında görüşlerinin daha da olumlu hale getirilmesi hedeflenmektedir.

- $\quad$ Restoran yönetimi hedef müşterinin alışkanlıkları ve satın alma gücüne bağlı olarak pazarlama stratejilerini belirlemesi gerekmektedir. Hedef müşteri kitlesi orta gelir düzeyinde ise ona göre fiyatlandırma uygulanmalı, menüde çok pahalı yiyeceklere yer verilmemelidir.

- Restoranlarda sıcak, samimi, güven veren bir ambiyans yaratılması gereklidir. Müssterilerin rahat edebilecekleri ergonomik masa ve sandalyeler kullanılmalıdır.

- Menünün açık ve anlaş1lır şekilde hazırlanmış olup, çok karışık ve anlaşılması zor yabancı kelimelerden mümkün olduğunda kaçınılmalıdır. Menü üretimden sorumlu olacak kişi olan aşçıbaşı ile beraber belirlenmelidir (Şarlar ve Şerefoğlu, 2015, s. 19).

- $\quad$ İster büyük isterse de küçük ölçekte rekabet eden bir işletme olsun, başarılı bir restoran yönetimi için güven duygusuna sahip, birbirleriyle anlaşabilen, uyumlu bir takım çalışması son derece önemlidir. İş gören seçimini deneyimli, insan ilişkilerinde başarılı, istekli ve iyi niyetli çalışanlardan seçip iyi bir ekip ruhunun yaratılması gerekmektedir.

\section{MÜŞTERINIIN RESTORAN SEÇIMINİ ETKILEYEN FAKTÖRLER}

Genel olarak restoranlar hakkında literatür taraması 1şığında bu bölümde araştırmanın asıl konusu olan restoran seçimini etkileyen faktörlerin neler olduğu incelenecektir. Tüketicilerin yaşamları boyunca mal ve hizmet seçiminde çok sayıda karar vermeleri gerekliliği gayet açıktır. Restoran seçimi de karar vermeyi gerektirir. Karar verme süreci, insanların iki ya da daha fazla alternatiften birini seçmesiyle tamamlanmış olur (Gregory ve Kim, 2004, s. 83). Restoran seçimi ile ilgili daha önce birçok araştırma yapılmıştır. Lewis (1981), Auty (1992) ve Clark ile Wood (1998)' un yaptıkları araştırmalar sonucunda genel itibariyle restoran seçiminde altı kıstasın etkili olduğu belirlenmiştir. Bu kıstaslar şu şekildedir: 
- $\quad$ Yemek Kalitesi,

- $\quad$ Menü / Yemek Çeşitliliği,

- Fiyat,

- $\quad$ Atmosfer / İmaj,

- Konum / Uygunluk,

- $\quad$ Servis.

Tablo 2. Restoran Seçiminde Etkili Faktörlerin Sıralanması Kaynak: Özdemir (2010).

\begin{tabular}{|l|l|l|l|}
\hline Etkili Faktörler & \multicolumn{3}{|l|}{ Önceki Çalışmalarda Ölçütlerin Sıralanması } \\
\hline & Lewis (1981) & Auty (1992) & $\begin{array}{l}\text { Clark ve Wood } \\
(1998)\end{array}$ \\
\hline Yemek Kalitesi & 1 & 2 & 2 \\
\hline Menü/Yemek Çeşitliliği & 2 & 1 & 1 \\
\hline Fiyat & 3 & 3 & 3 \\
\hline Atmosfer/İmaj & 4 & 4 & 4 \\
\hline Konum/Uygunluk & 5 & 5 & -- \\
\hline Servis & -- & -- & 5 \\
\hline
\end{tabular}

Yukarıdaki tablada restoran seçimiyle ilgili yer alan daha önceki araştırmalara göre etkili faktörlerin puanlaması sonucunda menü (yemek çeşitliliği) birinci, yemek kalitesi ikinci sırada yer almaktadır. Fiyat faktörü sıralamada üçüncü sırada yer alırken atmosfer (imaj) ise dördüncü sırada yer almaktadır. Konum (uygunluk) iki çalışmaya göre beșinci faktör olarak belirlenmiştir. Servis faktörü ise yalnızca Clark ve Wood ' un çalışmasında ilk beş kriterin içerisindedir. Bu çalışmaların ortaya koyduğu restoran seçim kararını etkileyen en önemli beş kriterin yemek çeşitliliği, yemek kalitesi, fiyat, atmosfer ve konum olduğu görülmektedir (Özdemir, 2010, s. 223; Yüksekbilgili, 2014, s. 6354).

Bu çalışmada, daha önce yapılan çalışmalar doğrultusunda restoran seçiminde tüketici tercihini etkileyen faktörlerden fiyat, hizmet kalitesi, ürün kalitesi, personel kalitesi ve atmosfer faktörleri belirlenmiş olup araştırmanın bu faktörler üzerinde şekillenmesi amaçlanmıştır.

\subsection{Müşterinin Restoran Seçimini Etkileyen Faktörler: Fiyat}

Müşteriler açısından fiyat, onlara ürün veya hizmet hakkında az da olsa bilgi veren, mal ve hizmetin ne olduğunun idrak edilmesinde ve analizinde yardımcı olan bir kavramdır (Örgün ve diğ. 2013, s. 30). Fiyat, özellikle tüketicilerin ürün ile ilgili bilgi sahibi olmadığ1 durumlarda kalitenin bir göstergesi olmaktadır. Tüketiciler, bu durumda sunulan ürün veya hizmetler arasındaki farklılıkları belirlemede fiyata dayanmaktadırlar (Atılgan, 2015, s. 15).

Öndoğan (2010)' a göre restoran işletmeciliğinde fiyatlandırma politikasını belirleyen restoran içi ve dışı etkenler şu şekildedir;

- Yasal tertipler, 
- İşletmenin sektördeki yeri ve konumu,

- İşletme maliyetleri,

- İşletmenin restoran sektöründeki yemek hizmeti türü,

- Fiyatlandirma amaçları,

- Ürün ve hizmetin niteliği,

- Tüketici tercih ve davranışları.

Fiyatlandırma kararını etkileyen kriterler; ilk olarak işletme maliyetleridir. İkinci olarak talep gelmektedir. Bir sonraki önemli kriter ise rekabettir. Rekabeti pazarlama ve fiyatlandırma hedefleri takip eder. Son olarak da ürünün kendisini ve çevresel faktörleri sıralamak mümkündür (Hançer ve diğ. 2007, s. 22).

\subsection{Müşterinin Restoran Seçimini Etkileyen Faktörler: Personel Kalitesi}

Tüketiciler için de olsa işletmeler içinde olsa bir hizmet alımı düşünüldüğünde bu işlemin ana katılımcıları müşteriler ve hizmet personelidir. Hizmet sunan işletmeler için personel müşteri memnuniyeti oluşturulmasında önemi mal ve mamul sunan işletmelerden oldukça fazladır (Aydın, 2016, s. 185). Hizmet sektöründe gerçekleştirilen çalışma durumu insan faktörüyle yürütülmektedir. Bu sebeple bir hizmet işletmesi için personel önemli bir etken olduğundan personelin seçiminde ve işe alınma evresinde dikkat edilmeli niteliğine göre personel seçimine karar verilmelidir (Kıngır, 2006, s. 458). Personel kalitesinde amaç ihtiyaç duyulan işe uygun personelin seçilmesi gerekir. Zira alanında deneyimsiz ve yanlış seçilen bir iş görenin maliyeti restoran için ek bir maliyet oluşturacaktır.

Restoran işletmeciliğinde personel kalitesinin sağlanması için personelin kişisel bakımına özen göstermesi, kibar olması, her durumda tebessüm etmeyi bilmesi, ekip çalışmasına uyumlu olması, kendi alanında gerekli eğitimi alması ve işini severek yapması gerekir. Restoranda sunulan hizmetin istenilen kalitede ve zamanında olması için personelin ekip ruhu ve koordineli şekilde çalışmaları gerekmektedir. Bu çalışma yöntemi restoranın pozitif anlamda tanıtımına ve karlılığına katkı sağlayacaktır.

\subsection{Müşterinin Restoran Seçimini Etkileyen Faktörler: Ürün Kalitesi}

İşletmelerin bağlı olduğu sektörde başarının en önemli faktörlerinden birisi de ürün kalitesidir. Ürün kalitesinin işletmelerin amaç ve hedeflerine ulaşabilmesi için öncelikli role sahip olması gerekir (Halis, 2007, s. 50). Müşteriler restorandaki yiyecek ve içeceklerin tazeliği, güvenliği, lezzetine oldukça önem vermekte ayrıca restoranının atmosferi, menünün zenginliği, servisin ilgi çekiciliği, bekleme zamanı, servis personelinin ilgisi, çocuk menüleri ve çocuklar için aktivite alanları, konfor, yeterli park alanı gibi pek çok unsuru restoran seçimlerinde dikkate almaktadırlar (Birdir ve Kale, 2014, s. 58).

Restoranda hizmetinin temel iş tanımı; müşterilerine arzu ettikleri yiyecek ve içecekleri hazırlayarak sunulmasıdır. O halde, yiyecek ve içeceklerin kaliteli ve sağlıklı ürünlerle insan sağlığına en elverişli pişirme metoduyla hazırlanıp, sunulması gerekir. Yiyecek ve içeceklerin hijyen kuralları çerçevesinde; her türlü hastalık unsurlarından arındırılmış olması elzemdir. Denizer (2008)' e göre hijyen ile temiz aynı anlama gelmemektedir. Temizlik, her hangi bir objenin üzerinde insan gözüyle görülebilen kirlerden arındırmış bir 
durumu ifade ederken; hijyenik temizlik insan sağlığına zarar veren mikroorganizmalardan arındırılmış temizlik olarak tanımlanmıştır. Ürün kalitesi sadece müşteriye sunulan yiyecek ve içecekleri kapsamamaktadır.

Hazır yemek sektöründeki işletmeler hakkında yapılan araştırmalarda hizmet kalitesini ölçmek için yiyecek ve içecek kalitesi önemli bir nitelik olarak ele alınmıştır. Bu çalışmalarda yiyecek içecek kalitesinin niteliği tüketici sadakatinde olumlu bir tesirinin olduğu iddia edilmektedir (Haciefendioğlu ve Koç, 2009, s. 163). Restorandaki yemek yeme hizmeti için kullanılan her ekipmanında kaliteli ve hijyenik olması istenir. Müşterinin iyi vakit geçirebilmesi için kullanılan koltuk veya sandalyelerin rahat ve ergonomik olması gereklidir. Sunulan ürün ve hizmetten tatmin olan bir müșteri restorana karşı duygusal bir bağ kuracak ve tekrar gelme eğilimi gösterecektir.

\subsection{Müşterinin Restoran Seçimini Etkileyen Faktörler: Atmosfer}

Tüketicilerin restoran seçimlerini etkileyen oldukça önemli bir diğer faktör restoran atmosferidir. Restoranın atmosferi, imaj1, konumu, müşterilerine rahat bir ortamda hizmet deneyiminin sunulması tüketim tavrına yönelik düşüncelerini etkilemektedir.

Restorandaki iş görenin işe bağlılığı, motivasyonu ve verimliliği kadar ergonomik ve kriterlere uygun restoran tasarımı oluşturularak bir atmosfer yaratmanın restorandan ekonomik getiri sağlayabilmenin ön koşullarından birisidir (Akın ve Gültekin, 2015, s. 253). Atmosfer denildiğinde restoranın iç ve dış görünümünün bir bütün halinde tüm unsurlarını ifade etmektedir. Birdir ve Kale (2014)' ye göre restoranlardaki yenilikler, dizayn, kullanılan ergonomik malzemeler, müzik, 1ş1k vb. gibi müşterinin dikkatini çekerek ve müşteri memnuniyeti oluşturarak tekrar gelme ihtimalini artırmaktadır. Restoranın ambiyans1, mobilyaların konumları, 1şıklandırma, tasarımda kullanılan eşyalar ve renkler gibi fiziksel özelliklerin yanı sıra, koku, müzik, ortamın sıcaklık, ferahlık gibi görülmeyen özelliklerde bir atmosfer meydana getirmede önem teşkil etmektedir. Restoranın fiziki bölümlerinden biri olan mutfağın ayrı bir önemi vardır. Mutfak bölümü, yiyecek ve içeceklerin hijyenik bir ortamda hazırlanarak pişirildiği ve işletmenin doğası gereği bazen de tüketildiği alandır. Mutfak işletmenin kalbini temsil eder. $\mathrm{Bu}$ sebeple işletme bünyesindeki konumu, tasarımı ve planlaması oldukça mühimdir (Çekal, 2013, s. 63).

Bir hizmet tüketiminde haz müşterinin hizmetin fiziksel ortamında kendini iyi hissetme derecesi ile yakından ilgilidir (Koç, 2015, s. 304). Bulunduğu bölgedeki rakip restoran işletmelerine rekabet üstünlügü kurmak isteyen restoranların, misafirlerinin restoranda geçirecekleri zamanın kalitesini artırmak, müşteri hoşnutluğunun sağlanmak ve tekrar gelme niyetlerini yükseltmek amacıyla özgün bir restoran atmosferine önem vermeleri gerekmektedir.

\subsection{Müşterinin Restoran Seçimini Etkileyen Faktörler: Hizmet Kalitesi}

Hizmet işletmelerinin başarılı olmalarının temel şartı kaliteli hizmet sunmalarıdır. Rakip işletmelerden farklılaşmanın ya da onlara karşı üstünlük sağlamanın yolu da kaliteli hizmet sunmaktan geçer (Küçükaltan, 2007, s. 62). Hacıefendi ve Koç (2009), hizmet kalitesinin müşteri bağl1lığ yaratmada önemli bir faktör olduğunu belirtmişlerdir. Müşteri sadakati üzerinde pozitif etkisi olduğu ileri sürülen hizmet kalitesi kapsamı içinde yer alan deneyimler, değer ve güvenilirlik gibi boyutların da müşteri bağlılığına olumlu etkisinin olduğunu söylemek mümkündür. 
Ürün metalaştırılmasının arttığı bir çağda hizmet kalitesi, farklılaşma ve sivrilme için en umut verici kaynaklardan birisidir. İyi hizmet vermek, bir müşteri yönelimi uygulamasının özünü teşkil eder (Kotler, 2010, s. 50). Hizmet sektörü içerisinde yer alan restoran işletmeleri, sunulan hizmetin kalitesini artırarak farklılıklarını ortaya koymalı ve verimlilik düzeylerini en üst seviyede tutmak zorundalardır. Üzerem (1997)' e göre hizmet kalitesini artırmak için restorana gelen müşterilere gereken özen, alaka ve yakınlığın gösterilmesi, istenilen hizmeti vaktinde ve kusursuz şekilde sunarak müşterinin güveninin kazanılmasına dikkat edilmelidir. Restoran personeli müşterilerine yardımcı olma konusunda istekli olduğunu göstermesi gerekmektedir. Ayrıca, restoran bünyesindeki hizmet içi eğitim programlara ağırlık verilerek hizmet kalitesinin artmasına katkı sağlanmış olunacaktır.

\section{YÖNTEM}

Tüketicilerin bir mal veya hizmet seçimlerinde birçok faktörden etkilenmekte ve çok fazla sayıda kriterin dikkate alınması gerekmektedir. Benzer şekilde, müşterilerin restoran seçimlerine etki eden birçok faktör bulunmakta olup, çok sayıda faktörün dikkate alınmasını gerektiren çok kriterli karar verme problemi olarak değerlendirilmektedir. $\mathrm{Bu}$ çalışma ile müşterilerin restoran seçimlerinde etkilendikleri faktörleri The Decision Making Trial and Evaluation Laboratory (DEMATEL) yöntemiyle değerlendirerek literatüre katkı sağlanması amaçlanmıştır.

\subsection{The Decision Making Trial and Evaluation Laboratory (DEMATEL) Metodu}

Karar verme süreci; metotları, koşulları ve türleri bakımından her dönem araştırma konusu olmuştur. Karar verme problemleri; doğası, kara vericinin yöntemleri ve kararın gayesi gereği, bir alternatifi seçmeyi, o alternatifleri en iyiden en kötüye doğru siralamayı veya daha önceden belirlenmiş homojen bölümlere ayırmayı gerektirir. Faktörlerin birden fazla olma halinde çok kriterli karar verme metotlarına başvurmak gerekmektedir. Çok kriterli karar verme, karar analizinin en çok tercih edilen yöntemlerini içeren bir dalıdır. Bu yöntem; faktörlerin seçimi, değerlendirilmesi ve bu faktörler arasından bir seçim yapılmasını, alternatif faktörlerin gruplandırılmasını veya önem derecelerine göre sıralanmasını sağlayan yöntemler barındırmaktadır. Çok kriterli karar verme yöntemi çok amaçlı ve çok nitelikli olmak üzere iki ayrı karar verme metoduna sahiptir. DEMATEL Yöntemi çok nitelikli karar verme teknikleri içerisinde yer alır (Altan ve Aydın, 2015, s. 101).

DEMATEL, neden-sonuç ilişkilerini analiz etmek için güçlü bir tekniktir (Büyüközkan ve diğ. 2017, s. 195). DEMATEL ilk olarak, Cenevre Battelle Memorial Enstitüsü Bilim ve

İnsan İlişkileri Programının çalışmaları sonucu, kompleks bir karar probleminde farklı kapsamlar arasındaki yapısal bağların kavranmasını basitleștirmek ve çözümlemeye katkıda sağlamak amacıyla geliştirilmiştir (Chu ve diğ. 2017, s. 3). DEMATEL metodu, kompleks problemlerin bileşenlerini sebep-sonuç kümelerine ayırır ve aralarındaki nedensellik bağını ortaya çıkarır. Bununla birlikte metot, direkt etkilerin yanında dolaylı etkileşimleri de hesaba katma olanağı sağlar (Çınar, 2013, s. 162). DEMATEL yöntemi sayesinde kriter ağırlıkları belirlenebilmekte, bu kriterler önem derecelerine göre siralanabilmektedir (Karaoğlan, 2016, s. 12). DEMATEL yönteminde diğer faktörleri daha fazla etkileyen ve onlardan daha yüksek bir önceliğe sahip olan kriter neden faktörü, diğer faktörlerin etkisi altında olan ve düşük önceliği olduğu kabul edilen faktör ise sonuç kriteri 
olarak tanımlanmaktadır (Aksakal ve Dağdeviren, 2010, s. 907). Bu yöntem son zamanlarda karmaşık problemlere sahip birçok konunun analizinde sıklıkla kullanılmakta olup uygulaması 4 adımdan oluşmaktadır (Sevim ve diğ. 2011, s. 218).

\section{Adım: (Doğrudan Etki Matrisini Oluşturma)}

Öncelikle uzman bir ekip tarafından ikili karşılaştırma ölçeği (Ar ve diğ. 2015, s. 287) kullanılarak faktörler yatay ve dikey düzlemde yazılır. Bir sonraki adımda faktörlerin ilişki boyutuna göre 0' dan 4' e kadar puanlandırılarak A başlangıç karar matrisi elde edilir. Bu matrisin kapsamı n x n' dir.

Tablo 3: DEMATEL Yönteminde Değerlendirme Ölçeği:

\begin{tabular}{|l|l|}
\hline Sayısal Değer & Tanım \\
\hline 0 & Etkisiz \\
\hline 1 & Düşük Etki \\
\hline 2 & Orta Etki \\
\hline 3 & Yüksek Etki \\
\hline 4 & Çok Yüksek Etki \\
\hline
\end{tabular}

$$
\mathrm{A}=\left[\begin{array}{ccccc}
a_{11} & \cdots & a_{1 j} & \cdots & a_{1 n} \\
\vdots & \ddots & \vdots & \ddots & \vdots \\
a_{i 1} & \cdots & a_{i j} & \cdots & a_{i n} \\
\vdots & \ddots & \vdots & \ddots & \vdots \\
a_{n 1} & \cdots & a_{n j} & \cdots & a_{n n}
\end{array}\right]
$$

\section{Adim:}

Oluşturulan A başlangıç karar matrisindeki satır ve sütunlarındaki en küçük değer (z) kullanılarak normalize edilerek $\mathrm{N}$ matrisi elde edilir. $\mathrm{N}$ matrisinin köşegen ögeleri 0'dır. 
$\mathrm{N}=\left[\begin{array}{ccccc}0 & \cdots & a_{1 j} & \cdots & a_{1 n} \\ \vdots & \ddots & \vdots & \ddots & \vdots \\ a_{i 1} & \cdots & 0 & \cdots & a_{i n} \\ \vdots & \ddots & \vdots & \ddots & \vdots \\ a_{n 1} & \cdots & a_{n j} & \cdots & 0\end{array}\right]$

\section{Adım:}

N matrisinin oluşturulmasının ardından kriterlerin, diğer kriterlere toplamda ne kadar etkiledikleriyle ilgili T matrisi oluşturulur. T matrisi için aşağıdaki Eşitlik 3 kullanılır.

$\mathrm{T}=\left[\mathrm{t}_{\mathrm{ij}}\right]_{\mathrm{n} \times \mathrm{n}}=\mathrm{N}(\mathrm{I}-\mathrm{N})^{-1}$

4. Adım:

Dikey ve yatay düzlemlerin toplamı D vektörü ve $R$ vektörü olarak, Eşitlik 4 ve 5 yardimiyla bulunur:

$$
\begin{aligned}
& D=\left[D_{i}\right]_{n \times 1}=\left[\sum_{j=1}^{n} t_{i j}\right]_{n \times 1} \\
& R=\left[R_{j}\right]_{1 \times n}^{\prime}=\left[\sum_{i=1}^{n} t_{i j}\right]_{1 \times n}
\end{aligned}
$$

Gönderici ve alıcı grupların belirlenmesi için toplam etki matrisindeki (T), satırlar toplamı (D) ve sütunlar toplamı (R) yardımıyla $D+R$ ve $D-R$ değerleri hesaplanır. Bu vektör kriterlerin ne kadar öneme sahip olduğunu göstermektedir. D ve R birbirinden çıkarılarak dikey vektör oluşturulur. D-R sonucuna göre kriterin cause veya effect grubuna gireceğine kararı verilir. D-R sonucu pozitif ise kriter cause grubunda, negatif ise effect grubundadır. Pozitif D-R değerine sahip kriterlerin diğer kriterler üzerinde daha yüksek etkiye sahip ve öncelikleri olduğu varsayılır. Negatif D-R değerinde olan kriterler ise diğerlerinden etkilendikleri ve diğer kriterlere göre düşük bir önceliğe sahip oldukları kabul edilir.

\section{UYGULAMA}

Bu çalışmada, restoran seçiminde tüketiciyi etkileyen faktörler, DEMATEL yöntemiyle analiz edilmiștir. Faktörleri belirlemek için yiyecek-içecek sektörüyle ilgili daha önce yayımlanmış akademik yazınlardan yararlanılmıştır. Restoran seçimini etkileyen faktörleri belirledikten sonra faktörlerin etki matrisini oluşturmak amacıyla pazarlama alanında uzman akademisyen tarafından DEMATEL Değerlendirme Ölçeği’ ne göre doldurulan matrislerin ortalaması alınarak Restoran Seçimi Direk Etki Matrisi oluşturulmuştur.

Tablo 4: DEMATEL Yöntemi Uygulamasında Belirlenen Kriterler Ve Kısa Açıklamaları 


\begin{tabular}{|l|l|l|}
\hline$(\mathrm{A})$ & Atmosfer & Restoran atmosferi \\
\hline$(\mathrm{F})$ & Fiyat & Restoranda belirlenen fiyatlandırma \\
\hline$(\mathrm{P})$ & Personel Kalitesi & Restoranda iş görenler ve iş gören kalitesi \\
\hline$(\ddot{U})$ & Ürün Kalitesi & Restoranda kullanılan ürün ve ürün kalitesi \\
\hline$(\mathrm{H})$ & Hizmet Kalitesi & Restoranda sunulan hizmet kalitesi \\
\hline
\end{tabular}

Restoran seçimini etkilen faktörler Tablo-4' de olduğu gibi belirlenmiștir. Çalıșmanın bundan sonraki kısmında belirlenen faktörler tabloda belirtildiği üzere kısaltmalar kullanılarak kriter hesaplamaları yapılacaktır.

Tablo 5: Direk Etki Matrisi

\begin{tabular}{|l|l|l|l|l|l|l|}
\hline KRİTERLER & $\mathrm{A}$ & $\mathrm{F}$ & $\mathrm{P}$ & $\ddot{U}$ & $\mathrm{H}$ & Toplam \\
\hline $\mathrm{A}$ & 0 & 2,66667 & 2,66667 & 2 & 4 & 11,33333 \\
\hline $\mathrm{F}$ & 2 & 0 & 2 & 2,33333 & 2,66667 & 9 \\
\hline $\mathrm{P}$ & 2,66667 & 2,66667 & 0 & 2,33333 & 4 & 11,66667 \\
\hline$\ddot{\mathrm{U}}$ & 2,33333 & 3,66667 & 1,66667 & 0 & 3 & 10,66667 \\
\hline $\mathrm{H}$ & 3,33333 & 4 & 4 & 3,33333 & 0 & 14,66667 \\
\hline Toplam & 10,3333 & 13 & 10,3333 & 10 & 13,6667 & 0 \\
\hline
\end{tabular}

Uzman görüşlerin kriter sonuçlarının aritmetik ortalaması alınarak Toblo-5' deki Direk Etki Matrisi oluşturulmuştur. Direk Etki Matrisindeki kriterlerin satır ve sütun toplamlarına bakıldığında en büyük değerin Hizmet Kalitesi (H) satırına ait olan 13,6667 değeri olduğu tespit edilmiş olup "z" değeri kabul edilmiştir.

Tablo 6: Toplam İlişki Matrisi

\begin{tabular}{|l|l|l|l|l|l|}
\hline & A & F & P & Ü & H \\
\hline A & 0,8614 & 1,2062 & 1,03795 & 0,97196 & 1,2973 \\
\hline F & 0,82485 & 0,84654 & 0,83296 & 0,82878 & 1,02744 \\
\hline $\mathrm{P}$ & 1,04378 & 1,23021 & 0,89328 & 1,00822 & 1,32098 \\
\hline$\ddot{U}$ & 0,93623 & 1,17662 & 0,91108 & 0,77642 & 1,16021 \\
\hline$H$ & 1,22926 & 1,48169 & 1,27329 & 1,208 & 1,28674 \\
\hline
\end{tabular}

Sonraki işlem ise DEMATEL metodundaki adımlar sırasıyla uygulanarak Normalleştirilmiş Direkt İlişki Matrisi oluşturulmuş daha sonrasında Tablo-6' daki " (F) Toplam İlişki Matrisi” ve Tablo 7' deki "Etkilenen ve Etkileyen Faktör Grupları” elde edilmiştir.

Tablo 7: Etkilenen ve Etkileyen Faktör Grupları

\begin{tabular}{|l|l|l|l|l|}
\hline & $\mathrm{D}$ & $\mathrm{R}$ & $\mathrm{D}+\mathrm{R}$ & $\mathrm{D}-\mathrm{R}$ \\
\hline Atmosfer & 5,374812 & 4,895519 & 10,27033 & 0,479293 \\
\hline Fiyat & 4,36057 & 4,034116 & 8,394686 & 0,326453 \\
\hline Personel Kalitesi & 5,496456 & 3,209268 & 8,705724 & 2,287188 \\
\hline Ürün Kalitesi & 4,960562 & 2,165493 & 7,126054 & 2,795069 \\
\hline Hizmet Kalitesi & 6,478977 & 1,229264 & 7,70824 & 5,249713 \\
\hline
\end{tabular}


Etki-Yönlü Grafik Diyagramı oluşturulurken dikkat edilmesi gereken ilk öncelik; Eşit Değerinin tespit edilmesidir. Tablo-6' daki değerlerin ortalaması alınarak eşit değerinin 1,06686 olduğu ortaya çıkmıştır. Bu değerin $(1,06686)$ üzerinde bir değere sahip olan Tablo-6' deki her bir hücre koyu zeminle belirtilmiştir. Eşit değeri baz alınarak etkilenen ve etkileyen faktör gruplarına göre oluşturulan grafik diyagramı ise Şekil-2' de verilmiştir.

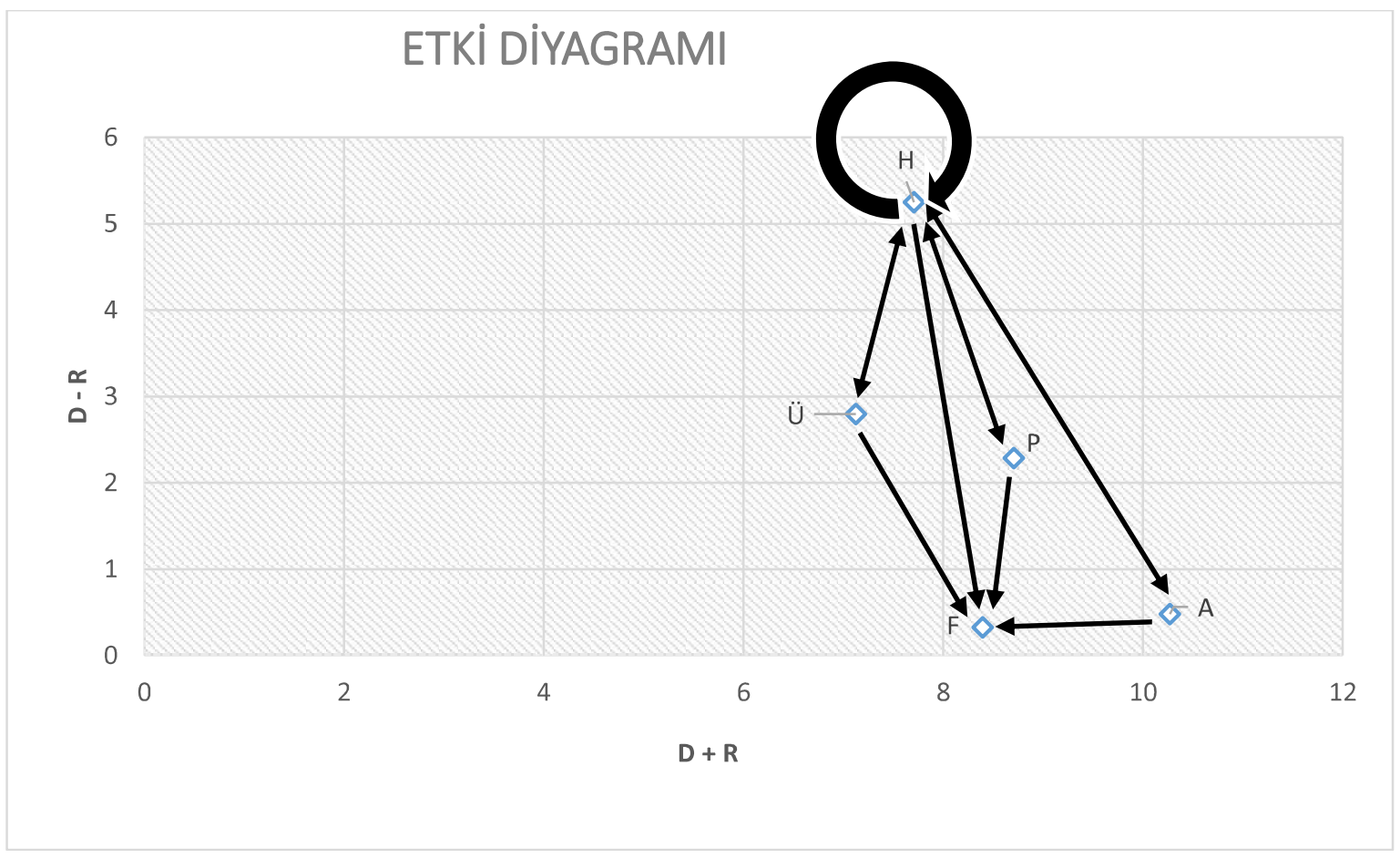

Şekil 2: Etki-Yönlü Grafik Diyagramı

\section{SONUÇ}

Kişilerin seçimleri, sosyal yaşantıları, eğitim ve gelir düzeyleri, psikolojik yapısı vb. etkenlere göre değişiklik arz etmektedir. Bu çalışmada, restoran seçiminde çoklu kriterlerin analizi ve alanında uzman kişilerin görüşleri ile restoran seçiminde tüketicileri etkileyen kriterlerin etki düzeyleri saptanarak, sektörde faaliyet gösteren işletmelerin, restoran seçimi faktörlerinden hangisine daha çok önem vermesi gerektiği yönünde bir örnek meydana getirilmiş ve model bir uygulama yapılmıştır.

DEMATEL metoduyla faktörlerin birbirlerini etkileme derecelerinin yanında sistemdeki bağlantılarda ölçümlenmiştir. $\mathrm{Bu}$ ölçümlerde Hizmet Kalitesi' nin restoran seçiminde belirlenen kriterler arasında en çok etkiye sahip olan kriter olduğu ortaya çıkmıştır. DEMATEL yöntemiyle yapılan bu uygulamada ölçümler ve hesaplamalar sonucunda restoran alanında uzman olan görüşlere göre önem derecesine sahip kriterler sırasıyla "Hizmet Kalitesi", "Ürün Kalitesi", "Personel Kalitesi", "Atmosfer" ve en az öneme sahip kriter ise "Fiyat" olarak belirlenmiştir.

Yapılan örnek uygulamaya göre, restoran işletme sahip ve yöneticilerinin müşteri memnuniyetini sağlayarak rakip işletmelere rekabet üstünlüğü kurması ve işletme 
karlılığını artırması için öncelikle işletmelerinde sunulan hizmet kalitesine odaklanmaları gerekmektedir. Yiyecek-içecek sektörü içerisinde yer alan restoran işletmeciliği bir hizmet işletmesi olduğundan dolayı müşteriye sunulacak hizmetin tam olarak ne anlam ifade ettiğini iyi anlamalı ve hizmet kalitesine gerekli önemin verilmesi gerekmektedir. Müssteri sadakatini sağlama açısından, müşterilerine daha kaliteli hizmetin nasıl verileceğini araştırmalıdır. Aynı şekilde restoranda kullanılan tüm ürünlerin çeşitli kalite ve gıda standartlarına uygun olmasına dikkat edilmelidir. Ürün kalitesi bir restoran için sadece hazırlanan yemeklerin kalitesi olarak anlaşılmamalıdır. Öyle ki restoranda kullanılan hizmet kapsamında her ne kadar ürün var ise hepsi ürün kalitesi faktörü içerinde yer almaktadır. Yemek yeme için kullanılan malzemeden lavaboda kullanılan peçeteye müşteri memnuniyeti esasına dayanarak kaliteli olmak zorundadır.

Ayrıca analiz sonucunda "Personel Kalitesi" faktörünün de önemli olduğunu görürüz. Bir işletmede müşteriyle ilk olarak irtibata geçecek ve onu bir misafir gibi ağırlayacak işletme personelidir. Restoran işletmeciliğinde personel; mutfak personeli ve salon personeli olarak ikiye ayrılmaktadır. Müşteri memnuniyeti ve sadakati açısından ikisine ayrı ayrı görevler yüklenmektedir. Mutfak personeli, lezzetli, taze, temiz yemek yaparken, salon personeli ise müşterinin gelişinden uğurlanışına kadar onu bir misafir gibi ağırlamalıdır.

Uygulamaya göre dördüncü önem sırası restoran atmosferine aittir. Günümüzde insanlar restoranlara yemek yeme ihtiyaçlarının yanında dinlenme ve sosyalleşme gibi gereksinimlerinden dolayı da gitmektedirler. $\mathrm{Bu}$ sebeple restoran her yeriyle nezih bir ortam olmalıdır. İnsanlar restorana geldiklerinde rahatlamalı ve dışarıdaki yoğun stresten bir nebze de olsa kurtulabilmelilerdir.

Genel itibariyle, müşteriler tercih ettiği restoranda huzurlu, hijyenik ve düzenli bir ortamda yemek ihtiyaçlarını karşılayabilmek, taleplerini her an iletebileceği yetkin bir iş gören ve almış olduğu hizmetin karşılığında makul bir fiyat beklentisi içerisinde olmaktadır. İşletmenin başarısını artırmaya yönelik hizmet kalitesini etkileyen atmosfer, müşteri beklentileri, dış çevre, restoran ambiyansı, iș görenlerin niteliği, kapsamlı ve açık bir menü, hijyen kuralları gibi temel kriterlerin dikkatli ve titiz bir şekilde ele alınması gerekmektedir. $\mathrm{Bu}$ önemli unsurlar dikkat edildiği takdirde müşteri memnuniyetinin oluşacağı aşikardır.

Bundan sonraki yapılacak olan uygulamalarda, restoran seçimi faktörlerinden daha fazla alternatif ile çalışmalar yapılabilir. Bu çalışmanın "Çok Kriterli Karar Verme Yöntemleri" nden biri olan DEMATEL yöntemi kullanılarak yapılacak çalışmalara yardımcı olacağı düşünülmektedir. Ayrıca restoran seçiminde tüketiciyi etkileyen faktörlerin etki ve önem derecelerine göre restoran yöneticilerinin uygulama sonucunu dikkate alarak, hem restoran değerinin hem de müşteri memnuniyetinin artmasına bir dayanak olması amaçlanmıştır.

\section{KAYNAKÇA}

Akarçay, E. ve Suğur, N. (2015). Dışarıda Yemek: Eskişehir'de Yeni Orta Sınıfın FastFood Yeme-İçme Örüntüleri, Sosyoloji Araştırmaları Dergisi, Cilt:18, Sayı:1, s.1-29.

Akın, G. ve Gültekin, T. (2015). Günümüz Restoran Tasarımında Kriterler, Süleyman Demirel Üniversitesi Mühendislik Bilimleri ve Tasarımı Dergisi. Cilt:3, Sayı:3, s.253. 
Aksakal, E. ve Dağdeviren, M. (2010), Anp ve Dematel Yöntemleri İle Personel Seçimi Problemlerine Bütünleşik Bir Yaklaşım, Gazi Üniversitesi Mühendislik Fakülte Dergisi, Cilt: 25, Say1: 4, s.905-913.

Albayrak, A. (2014). Müşterilerin Restoran Seçimlerini Etkileyen Faktörler: İstanbul Örneği, Anatolia: Turizm Araştırma Dergisi, Cilt:25, Sayı:2, s.190-201.

Altan, Ş. ve Aydın, E. K. (2015). Bulanık Dematel ve Bulanık Topsis Yöntemleri İle Üçüncü Parti Lojistik Firma Seçimi İçin Bütünleşik Bir Model Yaklaşımı, Süleyman Demirel Üniversitesi İktisadi ve İdari Bilimler Fakültesi Dergisi, Cilt: 20, Sayı:3, s.99-119. Ar, İ.M., Gökşen, H. ve Tuncer, M.A. (2015). Kablo Sektöründe Tedarikçi Seçimi İçin Bütünleşik Dematel-Ass-Vikor Yöntemlerinin Kullanılması. Ege Akademik Bakış Dergisi, Cilt: 15, Say1: 2, s.285-300.

Arıker, Ç. (2012). Tüketicilerin Restoran Seçiminde Kullandıkları Seçim Kriterleri ile Demografik Özellikleri Arasındaki İlişki, Öneri Dergisi, Cilt:10, Sayı:38, s.11-31.

Atılgan, K. Ö. (2015). Pazarlamada Fiyat: Davranışsal Bir Yaklaşım, (1.Baskı). Ankara: Akademisyen Kitabevi Yayıncılık.

Aydın, G. (2016). Hizmet İşletmelerinde Etkin Pazarlama Yöntemi, (1.Baskı). Ankara: Nobel Akademik Yayıncilık.

Bayat, B. (2014). Uygulamalı Sosyal Bilim Araştırmalarında Ölçme, Ölçekler ve 'Likert' Ölçek Kurma Tekniği, Gazi Üniversitesi İktisadi ve İdari Bilimler Fakültesi Dergisi, Cilt: 16, Say1: 3, s.1-24.

Bekar, A., Dönmez, F.,G. (2016). Tüketicilerin Dışarıda Yemek Yeme Nedenlerine İlişskin Bir Değerlendirme, International Peer-Reviewed E-Journal Social Sciences, Cilt: 11, Say1:1, s.1-15.

Birdir, S. S ve Kale, Y. E.(2014). Restoran İşletmelerinde Yenilik Uygulamaları: Mersin ve Adana Örneği, Seyahat ve Otel İşletmeciliği Dergisi, Cilt: 11, Sayı:3, s.57-72.

Bölükoğlu, İ. (1988). Kitleye Yönelik Yiyecek \& İçecek Hizmet İşletmelerinde Optimizasyon, (Yayımlanmamış Doktora Tezi), Dokuz Eylül Üniversitesi, İzmir.

Büyüközkan, G., Güleryüz ve Karpak, B. (2017). A New Combined If-Dematel and IfANP approach For CRM Partner Evalution, International Journal of Production Economics, Say1: 191, s.194-206).

Çekal, N. (2013). Yiyecek İçecek İşletmelerinde Mutfak Tasarımında Dikkat Edilmesi Gereken Faktörler, e-Journal of New World Sciences Academy, Cilt:8, Say1:1, s.62-66.

Çelik, M. (2012). Müşteri Memnuniyeti ve Hizmet Kalitesi Üzerine Adiyaman Üniversitesi Yemekhanesi' nde Bir Uygulama, Adıyaman Üniversitesi Sosyal Bilimler Enstitüsü Dergisi, Y1l: 5, Sayı: 10, s.29-54. 
Chu, J., Li, W., Yang, H. ve Yu, S. (2017). An Approach for Prioritizing Key Factors Affecting Air Travel Experience Based on Grey Theory and Dematel, Proceedings of the 23rd International Conference on Automation \& Computing, University of Huddersfield, s.1-6.

Çınar, Y. (2013). Kariyer Tercihi Probleminin Yapısal bir Modeli ve Riske Karşı Tutumlar: Olasılık DEMATEL Yöntemi Temelli Bütünleşik bir Yaklaşım, Sosyoekonomi Dergisi, Cilt: 19, Sayı: 19, s.157-186.

Denizer, D. (2008). Yiyecek İçecek Hizmetleri, F. Maviş (Ed.). (6-7). Eskişehir: Anadolu Üniversitesi Web-Ofset Tesisleri Yayını.

Gregory, S. ve Kim, J. (2004). Restaurant Choice, Journal of Foodservice Business Research, Cilt:7, Sayı:1 s.81-95.

Hacıefendioğlu, Ş. ve Koç, Ü. (2009). Hizmet Kalitesi Algılamalarının Müşteri Bağlılığına Etkisi ve Fast-Food Sektöründe Bir Araştırma, Cilt:18, Sayı:2, s.162-167.

Halis, M.,(2007), Toplam Kalite Yöntemi Perspektifinden İşletme Performans1, "İş, Güç" Endüstri İlişkiler ve İnsan Kaynakları Dergisi, Cilt:9, Sayı:4, s.47-65.

Hançer, M., Biçici, F. ve Tanrısevdi, A. (2007). Fiyat Sonu Yazım Stratejileri: Kafe ve Restoran Menü Fiyatlarının Öğrenci Algıları Üzerindeki Etkisini Belirlemeye Yönelik Nitel Bir Çalışma, Anatolia: Turizm Araştırmaları Dergisi, Cilt: 18, Sayı:1, s.21-32. İnan, H. (2010). Hizmet Pazarlamas1, (1. Bask1). Adana: Nobel Kitabevi.

Karakaş, A., Bilgin, Y. ve Kıngır, S. (2017). Restoran İşletmelerinde Müşteri Memnuniyetinin Müşteri Sadakatine Etkisi: Amasra' da Faaliyet Gösteren Balık Restoranları Üzerine Bir Araştırma, 4.Uluslararası Turizm ve Yönetim Araştırmaları Kongresi, s.600-619.

Karaoğlan, S. (2016). Dematel ve Vikor Yöntemleriyle Dış Kaynak Seçimi: Otel İşletmeciliği Örneği, Akademik Bakış Dergisi, Sayı: 55, s.9-24.

Karaoğlan, S. ve Şahin, S. (2016). Dematel ve Ahp Yöntemleri ile İşletmelerin Satın Alma Problemlerine Bütünleşik Bir Yaklaşım, DSRL Kamera Örneği, İşletme Araştırma Dergisi, Cilt:8, Sayı:2, s.359-375.

Kılıç, O. (2011). Restoran İşletmelerinde Hizmet Garantisi Uygulamaları ve Müssteri Tercihlerine Etkileri, Doktora Tezi, Adnan Menderes Üniversitesi, Aydın.

Kıngır, S.(2006). Bir Hizmet İşletmesi Olarak Beş Yıldızlı Otel İşletmelerindeki Yönetsel Sorunlar, Selçuk Üniversitesi Sosyal Bilimler Enstitü Dergisi, s.457-481.

Koç, E. (2015). Hizmet Pazarlaması ve Yönetimi, (1. Baskı). Ankara: Seçkin Yayıncılık. 
Kotler, P. (1974). Atmospherics As A Marketing Tool, Journal of Retailing, Cilt: 49, Sayı:4, s.48-64.

Kotler, P. (2005). Marketing Insights From A to Z, A. K. Bakkal (Çev).(9. Baskı). İstanbul: Mediacat Kitapları. Katipal Medya Hizmetleri.

Küçükaltan, G. (2007). Hizmet Kalitesi Kavramlar, Yaklaşımlar ve Uygulamalar. Ş. Gümüşoğlu, İ. Pırnar, P. Akan, A. Akbaba (Ed.). Hizmet Kalitesi Kavramına Genel Bir Yaklaşım ve Hizmet Kalitesinin Önemi İçinde (57-71). Ankara: Detay Anatolia Akademik Yayıncilık.

Öndoğan, E.N. (2010). Restoran Pazarlamasında Kullanılan Temel Pazarlama Karma Elemanları 'P', Ege Stratejik Araştırma Dergisi, s.1-25.

Örgün, E., Solunoğlu, A. ve Yayla, Ö. (2013). Yiyecek İçecek İşletmelerinde Ziyaretçilerin Psikolojik Fiyatlandırmaya İlişiklin Algıları: Ankara Örneği, Turizm ve Gastronomi Araştırmaları Dergisi. Cilt:1, Sayı:1, s.29-35.

Özdemir, B. (2010). Dışarıda Yemek Yeme Olgusu: Kurumsal Bir Model Önerisi, Anatolia Turizm Araştırmaları Dergisi, Cilt:21, Sayı:2, S.218-232.

Pırnar, İ. (2015). Yiyecek ve İçecek İşletmeleri Yöntemi, (1. Baskı). Ankara: Ertem Basım Yayın.

Rızaoğlu, B. ve Hançer, M. (2013). Menü ve Yönetim, (2. Baskı). Ankara: Detay Yayınc1lık.

Sevim, U., Ar, İ.M. ve Baki, B., (2011), Yeniliği Engelleyen Finansal Faktörlerin Dematel Yöntemi İle Değerlendirilmesi”, 11. Üretim Araştırmaları Sempozyumu, s. 215-223.

Şarlar, A.G. ve Şerefoğlu F. (2015). Yiyecek İçecek Sektörü İçin Yerel Girişimcilik, (1. Baskı). Ankara: Ertem Basım Yayın.

Üzerem, N. (1997). Hizmet Kalitesi Yöntemi, Pazarlama Dünyası Dergisi, Cilt:11, Sayı: 63, s.33-39.

Türksoy, A. (1997). Yiyecek ve İçecek Hizmetleri Yönetimi, (1.Bask1). Ankara: Turhan Kitabevi.

Yücenur, G., Y., Demirel, N., Ç., Ceylan, C. ve Demirel, T. (2011). Hizmet Değerlerinin Müşterilerin Davranışsal Niyetleri Üzerindeki Etkisinin Yapısal Eşitlik Modeli İle Ölçülmesi, Doğuș Üniversitesi, Cilt:12, Sayı:1, s.156-168.

Yüksekbilgili, Z. (2014). Restoran Seçim Ölçütleri Üzerine Bir Araştırma, Yaşar Üniversite Dergisi, Cilt:9, Say1:36, s.6261-6380.

Zencir, E. ve Kozak, M. (2014). Birinci Sınıf Restoranların Kurumsallaşma Durumu Üzerine Bir Araştırma: Türkiye Örneği, Seyahat ve Otel İşletmeciliği Dergisi, Cilt: 11, Say1:1, s.6-20. 
URL-1,(2012),

http://sektorlernedurumda.blogspot.com.tr/search/label/Kafe $\% 20 \mathrm{Sekt} \% \mathrm{C} 3 \% \mathrm{~B} 6 \mathrm{r} \% \mathrm{C} 3 \% \mathrm{BC}$ , Son Erişim Tarihi: 01 Kasım 2017.

URL-2, (2015). https://adilgurkan.blogspot.com.tr/2015/03/, Son Erişim Tarihi: 15 Kasım 2017.

URL-3, (2010). http://www.bilisimdergisi.org/s127/pdf/112-115.pdf , Son Erişim Tarih: 04 Aralık 2017.

URL-4, (2014). http://www.sozcu.com.tr/2014/ekonomi/restoranda-20-milyar-dolarlikyemek-yedik-501917/ , Son Erişim Tarihi: $10 \quad$ Aralı 2017. 